\title{
Laparoscopic approach to early stage endometrial cancer: is needed further evidence?
}

\author{
S Palomba ${ }^{*}$, A Falbo ${ }^{1}$, T Russo ${ }^{2}$, F Piccione ${ }^{2}$, M Biamonte $^{2}$, M Rocca $^{1}$, F Zullo ${ }^{1,2}$ \\ From de Senectute: Age and Health Forum \\ Catanzaro, Italy. 5-7 December 2009
}

\section{Background}

A recent meta-analysis of randomized controlled trials (RCTs) showed that laparoscopic approach to endometrial cancer was effective in terms of overall, diseasefree and cancer-related survival [1]. The aim of the current study was to update until September 2009 data from RCTs evaluating the effects of laparoscopic approach to endometrial cancer.

\section{Materials and methods}

Meta-analysis of randomized controlled trials (RCTs). Efficacy and safety data were evaluated.

\section{Results}

Three RCTs evaluating the efficacy and safety outcomes of laparoscopic surgery to treat early stage endometrial cancer were identified and included in the final analysis.

No significant difference in intra-operative complications $(\mathrm{OR}=1.5,95 \% \mathrm{CI} 0.7$ to $3.5, \mathrm{P}=0.442)$ was observed between laparoscopic and laparotomic approach to early stage endometrial cancer. Conversely, significant advantage in terms of post-operative complications $(\mathrm{OR}=0.5,95 \% \mathrm{CI} 0.3$ to $0.8, \mathrm{P}=0.008)$ were reported after laparoscopic surgery in comparison with laparotomic.

A significantly longer operative time was observed for the laparoscopic procedure than for the laparotomic one ( $\mathrm{OR}=35.6,95 \% \mathrm{CI} 1.9$ to $69.3, \mathrm{P}=0.038)$, even if a significant $(\mathrm{P}<0.001)$ heterogeneity was present across the analyzed studies. On the other hand, the intra-operative blood loss was significantly lower in patients treated with laparoscopy than in those treated with laparotomy $(\mathrm{OR}=-214.1,95 \% \mathrm{CI}-303.8$ to $-124.4, \mathrm{P}<0.001)$, even if a significant $(\mathrm{P}<0.001)$ heterogeneity was again present across the analyzed studies.

Pelvic nodes yield resulted similar between two surgical approaches $(\mathrm{OR}=1.0,95 \% \mathrm{CI}-0.3$ to $2.4, \mathrm{P}=0.134)$, whereas the para-aortic nodes yield was significantly higher after laparoscopic surgery $(\mathrm{OR}=-100.5,95 \% \mathrm{CI}$ -108.4 to $2.4, \mathrm{P}=0.134$ ).

No significant difference between laparoscopic and laparotomic approach to endometrial cancer in overall [odds ratio $(\mathrm{OR})=0.96,95 \%$ confidence index $(\mathrm{CI}) 0.51$ to $1.81, \mathrm{P}=0.976$ ] survival was observed (Figure 1 ).

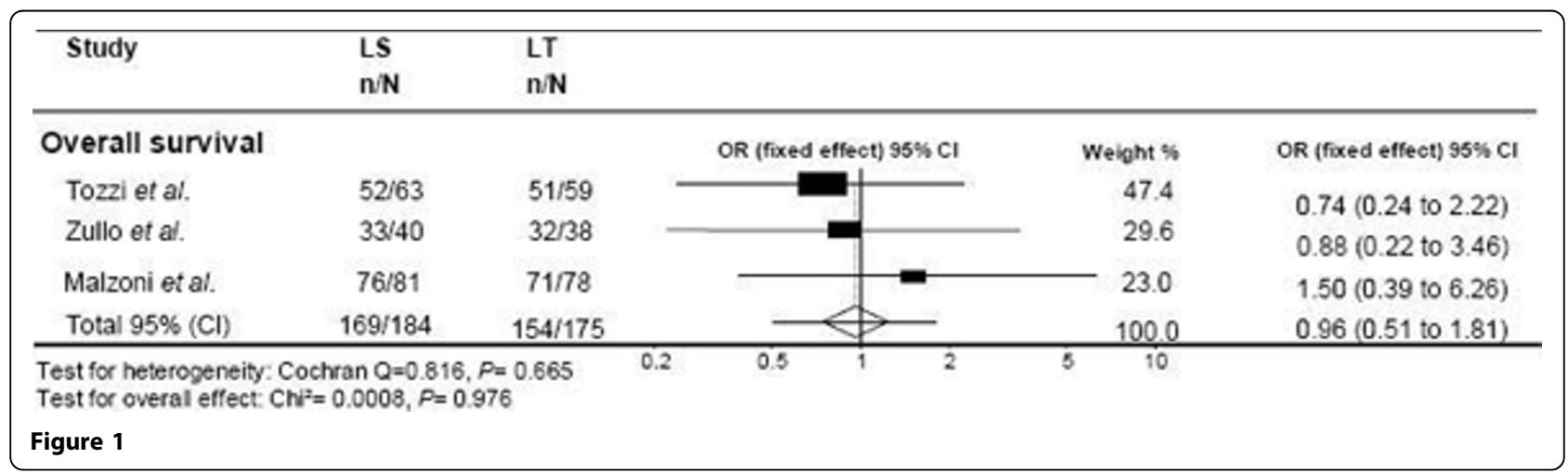

"Department of Gynecology \& Obstetrics, University "Magna Graecia" of Catanzaro, Italy 
Disease-free (OR=0.95, 95\% CI 0.51 to $1.80, \mathrm{P}=0.986)$ and cancer-related $(\mathrm{OR}=0.91,95 \% \mathrm{CI} 0.27$ to 3.06 , $\mathrm{P}=0.883$ ) survival has been demonstrated to be not different between two surgical approaches. No significant heterogeneity was observed between studies in any efficacy outcome evaluated.

\section{Conclusions}

Both laparoscopy and laparotomy are two effective approaches for treating patients with early stage endometrial cancer.

\section{Author details}

'Department of Gynecology \& Obstetrics, University "Magna Graecia" of Catanzaro, Italy. ${ }^{2}$ Gynecologic Oncology Unit, Cancer Center of Excellence

"Tommaso Campanella" of Germaneto, Catanzaro, Italy.

Published: 19 May 2010

\section{Reference}

1. Palomba S, Falbo A, Mocciaro R, Russo T, Zullo F: Laparoscopic treatment for endometrial cancer: a meta-analysis of randomized controlled trials (RCTs). Gynecol Oncol 2009, 112:415-421.

doi:10.1186/1471-2318-10-S1-A70

Cite this article as: Palomba et al:: Laparoscopic approach to early stage endometrial cancer: is needed further evidence? BMC Geriatrics 2010

10(Suppl 1):A70.

Submit your next manuscript to BioMed Central and take full advantage of:

- Convenient online submission

- Thorough peer review

- No space constraints or color figure charges

- Immediate publication on acceptance

- Inclusion in PubMed, CAS, Scopus and Google Scholar

- Research which is freely available for redistribution

Submit your manuscript at www.biomedcentral.com/submit 